\title{
An ICT-Based Approach to Ratiometric Fluorescence Imaging of Hydrogen Peroxide Produced in Living Cells
}

\author{
Duangkhae Srikun, Evan W. Miller, Dylan W. Domaille, and Christopher J. Chang* \\ Department of Chemistry, University of California, Berkeley, CA 94720
}

Synthetic Materials and Methods. Silica gel P60 (SiliCycle) was used for column chromatography. Microwave reactions were performed using a CEM Intelligent Explorer/Discover (Matthews, NC). 4-Amino-1,8-naphthalic anhydride $\mathbf{1}$ and catalase from bovine liver were purchased from Sigma Aldrich (St. Louis, MO). NOC5 (3-(2-hydroxy-1methylethyl-2-nitrosohydrazino)-1-propanamine) was purchased from Calbiochem (La Jolla, CA). 4-(4,4,5,5-Tetramethyl-1,3,2-dioxaborolan-2-yl)benzaldehyde was purchased from Oakwood (West Columbia, SC). Live/Dead cell vitality assay kit with $\mathrm{C}_{12}$-resazurin and SYTOX green was purchased from Invitrogen/Molecular Probes (Carlsbad, CA). All other chemicals were purchased from Sigma-Aldrich (St. Louis, MO) and were used as received. ${ }^{1} \mathrm{H}$ NMR spectra were collected in $\mathrm{CDCl}_{3}$ or $\mathrm{DMSO}-\mathrm{d}_{6}$ (Cambridge Isotope Laboratories, Cambridge, MA) at $25{ }^{\circ} \mathrm{C}$ on a Bruker AVQ-400 spectrometer at the College of Chemistry NMR Facility at the University of California, Berkeley. All chemical shifts are reported in the standard $\delta$ notation of parts per million. Mass spectral analyses were carried out at the College of Chemistry Mass Spectrometry Facility at the University of California, Berkeley.

4-Amino- $N$-(2-(2-hydroxyethoxy)ethyl)naphthalimide (2). A mixture of 1 (400 $\mathrm{mg}, 1.88$ $\mathrm{mmol})$ and 2-(2-aminoethoxy)ethanol $(250 \mu \mathrm{L}, 2.50 \mathrm{mmol})$ in DMF $(3 \mathrm{~mL})$ in a heavy-walled test tube was heated by microwave irradiation for $90 \mathrm{~min}$ at $150{ }^{\circ} \mathrm{C}$. After cooling to room temperature, the solution was poured into $5 \%$ aq. $\mathrm{KHSO}_{4}$ to precipitate the desired product as a yellow solid (502 mg, $1.66 \mathrm{mmol}, 89 \%$ yield). ${ }^{1} \mathrm{H}$ NMR (400 MHz, DMSO-d 6 ) $\delta 8.58(\mathrm{~d}, 1 \mathrm{H}, J=$ $8.0 \mathrm{~Hz}), 8.39(\mathrm{~d}, 1 \mathrm{H}, J=8.0 \mathrm{~Hz}), 8.15(\mathrm{~d}, 1 \mathrm{H}, J=8.4 \mathrm{~Hz}), 7.63(\mathrm{t}, 1 \mathrm{H}, J=8.1 \mathrm{~Hz}), 7.44(\mathrm{~s}, 2 \mathrm{H})$, $6.80(\mathrm{~d}, 1 \mathrm{H}, J=8.4 \mathrm{~Hz}), 4.55(\mathrm{~s}-\mathrm{br}, 1), 4.16(\mathrm{t}, 2 \mathrm{H}, J=6.0 \mathrm{~Hz}), 3.57(\mathrm{~s}, 2 \mathrm{H}, J=6.0 \mathrm{~Hz}), 3.42(\mathrm{~m}$, $4 \mathrm{H})$.

4-Amino- $N$-(2-(2-acetoxyethoxy)ethyl)naphthalimide (3). A mixture of 2 (100 $\mathrm{mg}, 0.33$ mmol) and acetic anhydride $(40 \mu \mathrm{L}, 0.39 \mathrm{mmol})$ in pyridine $(2 \mathrm{~mL})$ was stirred at room temperature overnight. The solvent was removed under reduced pressure. Purification by flash column chromatography (silica gel, 1:1 EtOAc/ $\mathrm{CH}_{2} \mathrm{Cl}_{2}$ ) gave 4 as an orange solid (60 mg, 0.18 mmol, 53\% yield). ${ }^{1} \mathrm{H}$ NMR (400 MHz, DMSO-d 6 ) $\delta 8.58(\mathrm{~d}, 1 \mathrm{H}, J=8.0 \mathrm{~Hz}), 8.39(\mathrm{~d}, 1 \mathrm{H}, J=$ $8.0 \mathrm{~Hz}), 8.15(\mathrm{~d}, 1 \mathrm{H}, J=8.4 \mathrm{~Hz}), 7.63(\mathrm{t}, 1 \mathrm{H}, J=8.1 \mathrm{~Hz}), 7.44(\mathrm{~s}, 2 \mathrm{H}), 6.80(\mathrm{~d}, 1 \mathrm{H}, J=8.4 \mathrm{~Hz})$, $4.16(\mathrm{t}, 2 \mathrm{H}, J=6.0 \mathrm{~Hz}), 4.02(\mathrm{~s}, 2 \mathrm{H}, J=6.0 \mathrm{~Hz}), 3.60(\mathrm{~m}, 4 \mathrm{H}), 1.87(\mathrm{~s}, 3 \mathrm{H})$.

Peroxy Lucifer 1 (PL1, 5). To a mixture of 3 (60 mg, $0.17 \mathrm{mmol}$ ) and DMAP (64 mg, 0.52 $\mathrm{mmol})$ in toluene $(3 \mathrm{~mL})$ was added a solution of triphosgene $(52 \mathrm{mg}, 0.17 \mathrm{mmol})$ in toluene dropwise. The resulting solution was heated to reflux for $3 \mathrm{~h}$. After cooling to room temperature, the reaction mixture was diluted with $\mathrm{CH}_{2} \mathrm{Cl}_{2}(6 \mathrm{~mL})$ and filtered. To the filtrate was added the boronated benzyl alcohol $4^{1}(42 \mathrm{mg}, 0.18 \mathrm{mmol})$ and the solution was stirred at room temperature for an additional three hours. The reaction was then concentrated and purified by flash column chromatography (silica gel, 1:1 EtOAc/ $\mathrm{CH}_{2} \mathrm{Cl}_{2}$ ) to give PL1 as a yellow solid (40 $\mathrm{mg}, 0.07$ mmol, 38\% yield). ${ }^{1} \mathrm{H}$ NMR $\left(400 \mathrm{MHz}, \mathrm{CDCl}_{3}\right) \delta 8.62(\mathrm{~d}, 1 \mathrm{H}, J=8.0 \mathrm{~Hz}), 8.60(\mathrm{~d}, 1 \mathrm{H}, J=8.4$ 
$\mathrm{Hz}), 8.40(\mathrm{~d}, 1 \mathrm{H}, J=8.0 \mathrm{~Hz}), 8.17(\mathrm{~d}, 1 \mathrm{H}, J=8.4 \mathrm{~Hz}), 7.86(\mathrm{~d}, 2 \mathrm{H}, J=7.6 \mathrm{~Hz}), 7.77(\mathrm{t}, 1 \mathrm{H}, J=$ $8.0 \mathrm{~Hz}), 7.49(\mathrm{br} \mathrm{s}, 1 \mathrm{H}), 7.48(\mathrm{~d}, 2 \mathrm{H}, J=7.6 \mathrm{~Hz}), 5.32(\mathrm{~s}, 2 \mathrm{H}), 4.44(\mathrm{t}, 2 \mathrm{H}, J=6.0 \mathrm{~Hz}), 4.19(\mathrm{t}$, $2 \mathrm{H}, J=4.4 \mathrm{~Hz}), 3.84(\mathrm{t}, 2 \mathrm{H}, J=6.0 \mathrm{~Hz}), 3.75(\mathrm{t}, 2 \mathrm{H}, J=4.4 \mathrm{~Hz}), 1.98(\mathrm{~s}, 3 \mathrm{H}), 1.36(\mathrm{~s}, 12 \mathrm{H}) .{ }^{13} \mathrm{C}$ NMR $\left(400 \mathrm{MHz}, \mathrm{CDCl}_{3}\right) \delta 171.3,164.5,164.0,153.2,139.2,138.4,135.4,132.9,131.6,129.2$, $128.0,126.9,126.2,123.6,123.0,118.0,84.2,77.5,68.7,68.2,64.0,39.2,25.1,21.2$. HRFABMS: calcd for $\mathrm{C}_{32} \mathrm{H}_{37} \mathrm{~N}_{2} \mathrm{O}_{9} \mathrm{~B}[\mathrm{M}+1]^{+} 603.2436$, found 603.2509 .

Spectroscopic Materials and Methods. Millipore water was used to prepare all aqueous solutions. All spectroscopic measurements were performed in $20 \mathrm{mM}$ HEPES buffer, pH 7.4. Absorption spectra were recorded using a Varian Cary 50 spectrophotometer (Walnut Creek, CA) and fluorescence spectra were recorded using either a Jobin-Yvon SPEX FluoroMax-2 scanning spectrofluorometer (Edison, NJ) or a Photon Technology International Quanta Master 4 L-format scanning spectrofluorometer (Lawrenceville, NJ) equipped with an LPS-220B 75-W xenon lamp and power supply, A-1010B lamp housing with integrated igniter, switchable 814 photon-counting/analog photomultiplier detection unit, and MD5020 motor driver. Samples for absorption and emission measurements were contained in $1-\mathrm{cm} \times 1-\mathrm{cm}$ quartz cuvettes $(3.5-\mathrm{mL}$ volume, Starna, Atascadero, CA). Fluorescence quantum yields were determined by reference to fluorescein in basic ethanol $(\Phi=0.97) .^{2}$

Reactive oxygen species ( $200 \mu \mathrm{M}$ unless otherwise stated) were administered to PL1 in $20 \mathrm{mM}$ HEPES (pH 7.4, $25{ }^{\circ} \mathrm{C}$ ) as follows. $\mathrm{H}_{2} \mathrm{O}_{2}$, tert-butylhydroperoxide (TBHP), and hypochlorite $(\mathrm{NaOCl})$ were delivered from $30 \%, 70 \%$, and $10 \%$ aqueous solutions respectively. Hydroxyl radical $(\cdot \mathrm{OH})$, and tert-butoxy radical $\left(. \mathrm{O}^{\mathrm{t}} \mathrm{Bu}\right)$ were generated by reaction of $1 \mathrm{mM} \mathrm{Fe}{ }^{2+}$ with 200 $\mu \mathrm{M} \mathrm{H}_{2} \mathrm{O}_{2}$ or TBHP, respectively. Nitric oxide (NO) was generated from NOC5 (stock solution 1 $\mathrm{mM}$ in $0.1 \mathrm{M} \mathrm{NaOH}$ ); degradation of $280 \mu \mathrm{M}$ NOC5 in aqueous solution will generate $200 \mu \mathrm{M}$ NO after $60 \mathrm{~min}$. Superoxide $\left(\mathrm{O}_{2}^{-}\right)$was delivered from the enzymatic reaction of xanthine oxidase $(0.02 \mathrm{unit} / \mathrm{mL})$ and hypoxanthine $(1 \mathrm{mM}$ in phosphate buffer $\mathrm{pH} 7.8)$ in the presence of 5 units catalase as a scavenger for any $\mathrm{H}_{2} \mathrm{O}_{2}$. The rate of $\mathrm{O}_{2}{ }^{-}$production observed from the reduction of cytochrome c was $1.5 \mu \mathrm{M} / \mathrm{min}$. Singlet oxygen $\left({ }^{1} \mathrm{O}_{2}\right)$ was generated by UV irradiation of Sensitox II ( $1 \mathrm{mg}$, kindly provided as a gift from Prof. Kris McNeill, University of Minnesota) in dye solution using $450 \mathrm{~W}$ mercury arc lamp powered by Aceglass power supply for 2 min. Caution: Reactive oxygen species such as singlet oxygen are highly oxidizing and should be handled with care.
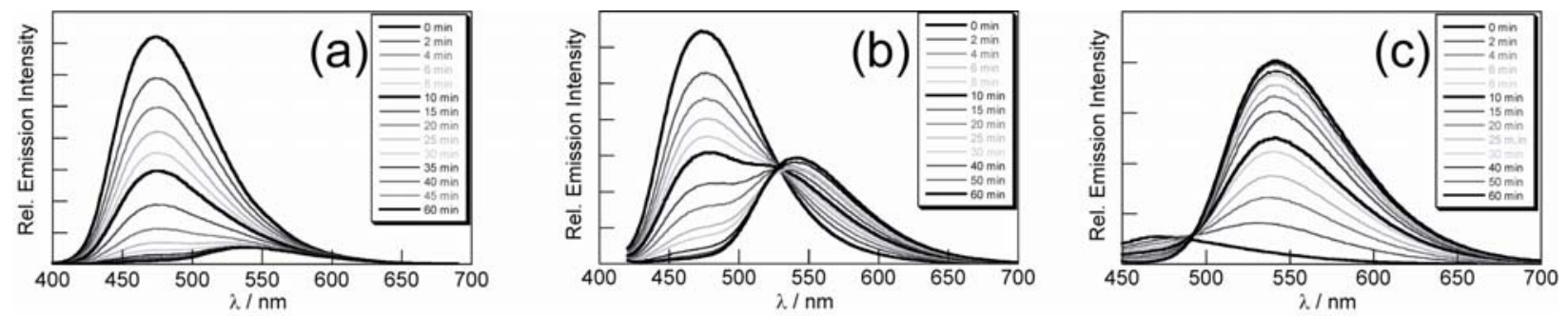

Figure S1: Fluorescence response of $5 \mu \mathrm{M}$ PL1 to $1 \mathrm{mM} \mathrm{H}_{2} \mathrm{O}_{2}$ with excitation at (a) $380 \mathrm{~nm}$ (b) $410 \mathrm{~nm}$, and (c) $435 \mathrm{~nm}$. 


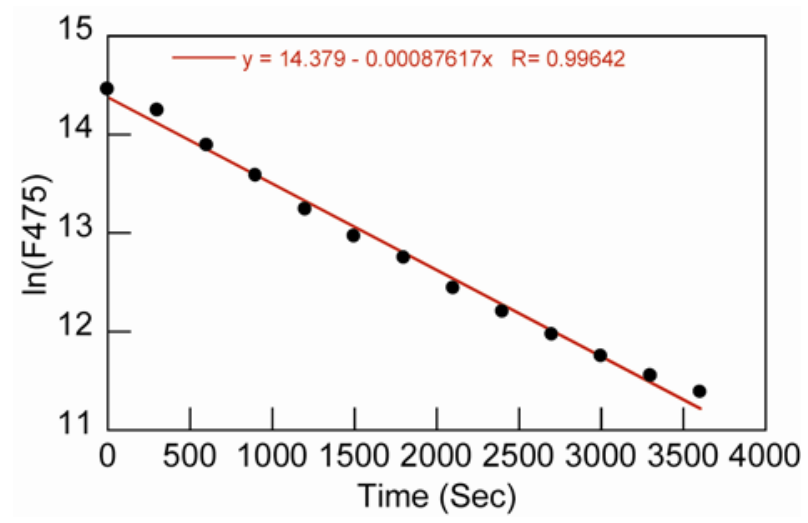

Figure S2: Kinetic plot of fluorescence emission intensity at $475 \mathrm{~nm}$ of the pseudo-first order reaction of $1 \mu \mathrm{M}$ PL1 to $1 \mathrm{mM} \mathrm{H}_{2} \mathrm{O}_{2}$, using excitation wavelength at $380 \mathrm{~nm}$. The slope of the plot corresponds to the observed reaction rate of $8.8 \times 10^{-4} \mathrm{~s}^{-1}$.

Preparation and Staining of Cell Cultures. RAW264.7 macrophages were cultured in Dulbecco's Modified Eagle Medium (DMEM) containing high glucose with GlutaMAX ${ }^{\mathrm{TM}}$ (Invitrogen, Carlsbad, CA) and supplemented with 10\% Fetal Bovine Serum (FBS, Hyclone). Cells were split 1/30 twice a week. One day before imaging, cells were passed and plated on 18$\mathrm{mm}$ glass coverslips coated with poly-L-lysine $(50 \mu \mathrm{g} / \mathrm{mL}$, Sigma, St. Louis, MO). HEK $293 \mathrm{~T}$ cells were cultured in DMEM with 10\% FBS, and glutamine $(2 \mathrm{mM})$. One day before imaging, cells were passed and plated on 25-mm glass coverslips. Aliquots of PL1 (2 mM stock solution in DMSO), phorbol myristate acetate (PMA, $1 \mathrm{mg} / \mathrm{mL}$ stock solution in DMSO) and $\mathrm{H}_{2} \mathrm{O}_{2}(50$ $\mathrm{mM}$ stock solution in Millipore water) were added directly to the cell media, and cells were washed with PBS buffer before imaging.

Fluorescence Imaging Experiments. Confocal fluorescence imaging was performed with a Zeiss LSM510 NLO Axiovert 200 laser scanning microscope and 40x or 63x water-immersion objective lens with 2x optical zoom. Excitation of PL1-loaded cells was carried out with MaiTai two-photon laser at 820-nm pulses (mode-locked Ti:sapphire laser, Tsunami Spectra Physics). Blue emission was collected using a META detector with a 430-495 nm window, and green emission was collected with a 535-600 nm window. PL1 $(5-10 \mu \mathrm{M})$ was incubated with live cell samples for $15 \mathrm{~min}$ at $25{ }^{\circ} \mathrm{C}$ before addition of $\mathrm{PMA}$ or $\mathrm{H}_{2} \mathrm{O}_{2}$. Data were analyzed using ImageJ software (author: Wayne Rasband, NIH) and Ratio Plus plugin (programmer: Paulo Magalhes, University of Padua, Italy).

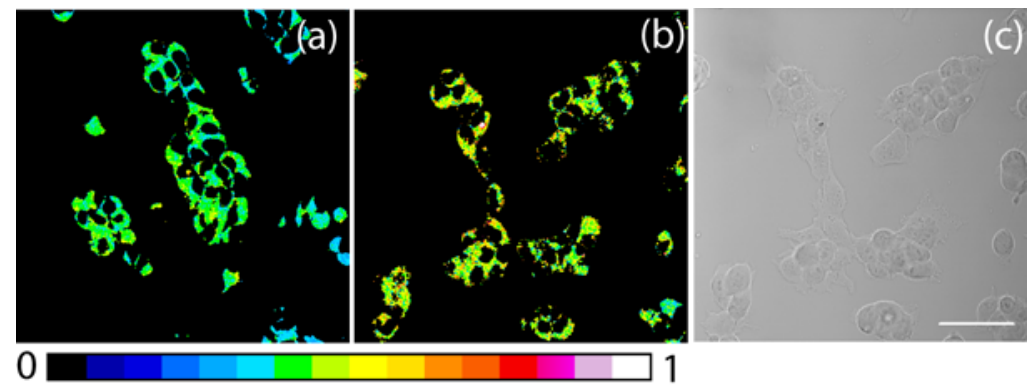

Figure S3: Confocal, ratiometric fluorescence images of HEK 293T cells. Images displayed in pseudocolor represent the ratio of emission intensities collected in optical windows between 535600 and 430-495,respectively, upon two-photon excitation at $820 \mathrm{~nm}$. (a) Cells incubated with 10 $\mu \mathrm{M}$ PL1 for 15 min at $37^{\circ} \mathrm{C}$. (b) PL1-loaded cells after treatment with $100 \mu \mathrm{M} \mathrm{H}_{2} \mathrm{O}_{2}$ for 60 min. (c) Brightfield images of cells in panel (b) with $50 \mu \mathrm{m}$ scale bar. 
Cell Viability Assays. The viability of cells loaded with PL1 was evaluated both by the Trypan Blue exclusion test and Live/Dead cell vitality assay with $\mathrm{C}_{12}$-resazurin and SYTOX green. RAW 264.7 cells were incubated with $10 \mu \mathrm{M}$ PL1 for $6 \mathrm{~h}$. Cell suspensions were obtained by trypsinizing and washing three times with PBS containing 1\% FBS. For the Trypan Blue exclusion test, equal volumes of cell suspension and $0.4 \%$ Trypan Blue Stain were mixed and allowed to stand for 10 min before cell counting. Cells incubated with PL1 were alive and viable. For the live/dead vitality assay, cell suspensions were incubated with $500 \mathrm{nM} \mathrm{C}_{12}$-resazurin and $40 \mathrm{nM}$ SYTOX green for $15 \mathrm{~min}$ at $37^{\circ} \mathrm{C}$ and keep in ice bath prior to cell counting with a FACSCalibur flow cytometer (BD Biosciences Immunocytometry Systems) using $488 \mathrm{~nm} \mathrm{Ar}$ laser excitation. The fluorescent emission from $\mathrm{C}_{12}$-resazurin and SYTOX green was collected using $585 \mathrm{~nm}$ bandpass filter (FL2), and $530 \mathrm{~nm}$ bandpass filter (FL1) respectively. Dead cells controls were obtained by incubation of RAW 264.7 cells with 30\% ethanol for $2 \mathrm{~h}$. Forward light scatter (FSC) and side scatter (SSC) plots alone displayed the significant difference in size and granulation between live and dead cells. Cells incubated with PL1 were largely viable as shown in the positive stain with $\mathrm{C}_{12}$-resazurin and negative stain with SYTOX green (Figure S4).
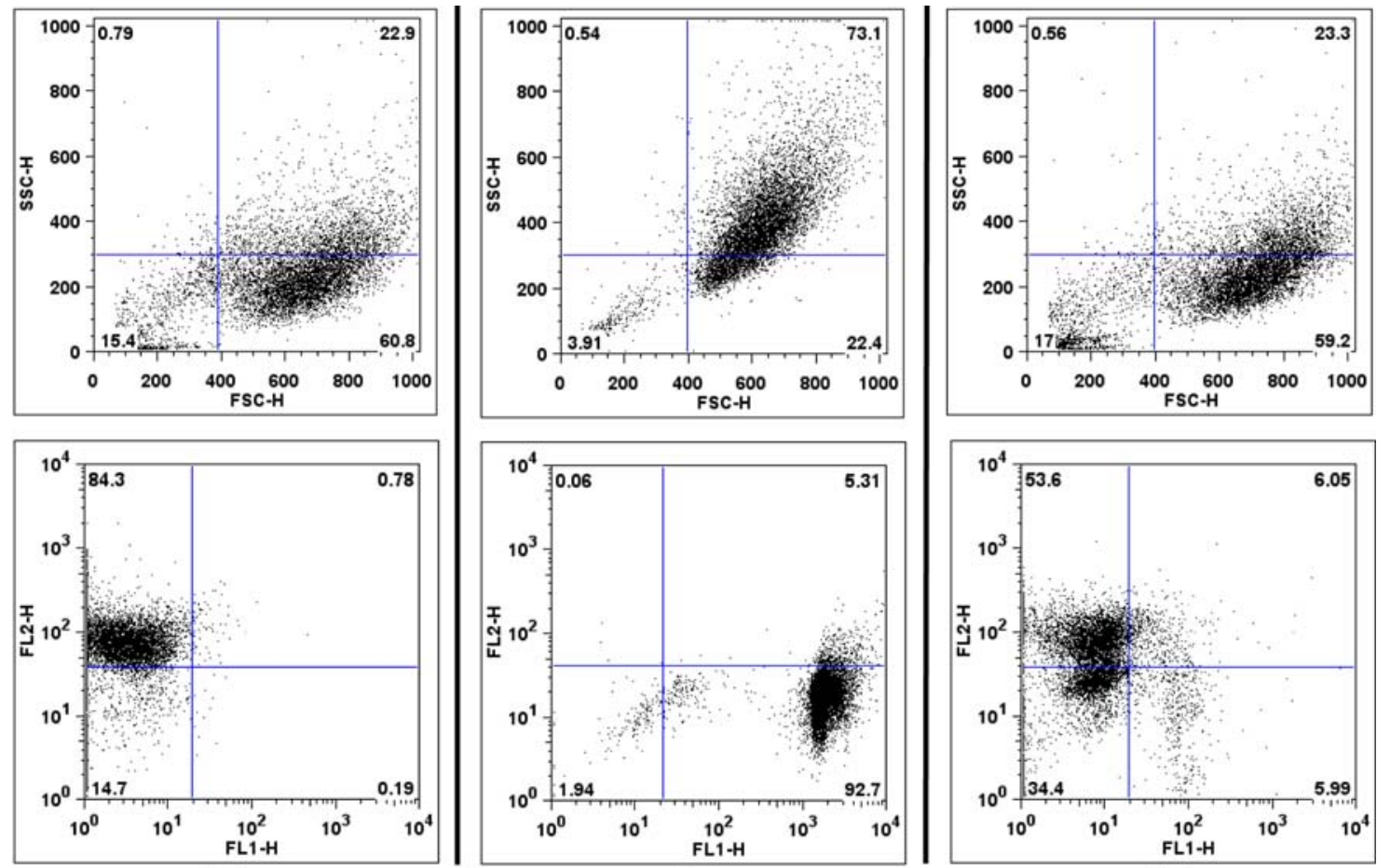

(a)

(b)

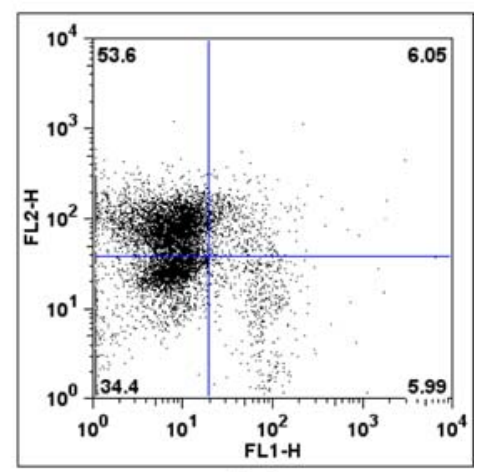

(c)

Figure S4: Flow cytometry test for viability of RAW 264.7 cells using SYTOX Orange for labeling of dead cell. (a) Viable cells. (b) Dead cell controls. (c) Cells incubated with PL1 for 6 hours, confirming their viability.

\section{References}

1. De Filippis, A.; Morin, C.; Thimon, C. Syn. Commun. 2002, 32, 2669-2672.

2. Seybold, P. G.; Garterman, M.; Callis, J. Photochem. Photobiol. 1969, 9, 229-242. 